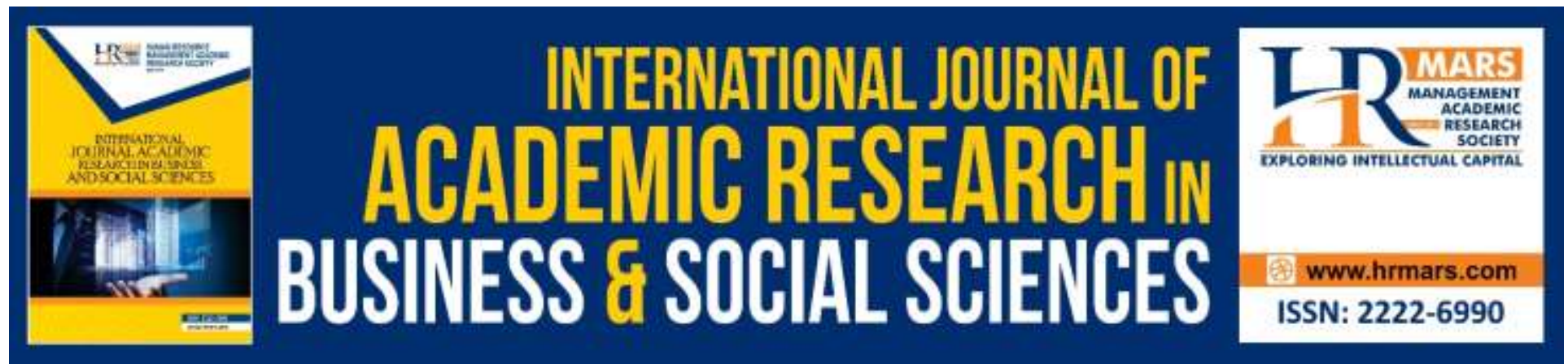

\title{
An Exploratory Study of Integrated Management System on Food Safety and Organic Certifications
}

Sarina Abdul Halim Lim, Anjar Priyono \& Chew Hueih Ming

To Link this Article: http://dx.doi.org/10.6007/IJARBSS/v10-i3/7111

DOI:10.6007/IJARBSS/v10-i3/7111

Received: 08 February 2020, Revised: 24 February 2020, Accepted: 17 March 2020

Published Online: 31 March 2020

In-Text Citation: (Lim et al., 2020)

To Cite this Article: Lim, S. A. H., Priyono, A., \& Ming, C. H. (2020). An Exploratory Study of Integrated Management System on Food Safety and Organic Certifications. International Journal of Academic Research in Business and Social Sciences, 10(3), 882-892.

Copyright: @ 2020 The Author(s)

Published by Human Resource Management Academic Research Society (www.hrmars.com)

This article is published under the Creative Commons Attribution (CC BY 4.0) license. Anyone may reproduce, distribute, translate and create derivative works of this article (for both commercial and non-commercial purposes), subject to full attribution to the original publication and authors. The full terms of this license may be seen

at: http://creativecommons.org/licences/by/4.0/legalcode

Vol. 10, No. 3, 2020, Pg. 882 - 892

http://hrmars.com/index.php/pages/detail/IJARBSS

JOURNAL HOMEPAGE

Full Terms \& Conditions of access and use can be found at http://hrmars.com/index.php/pages/detail/publication-ethics 


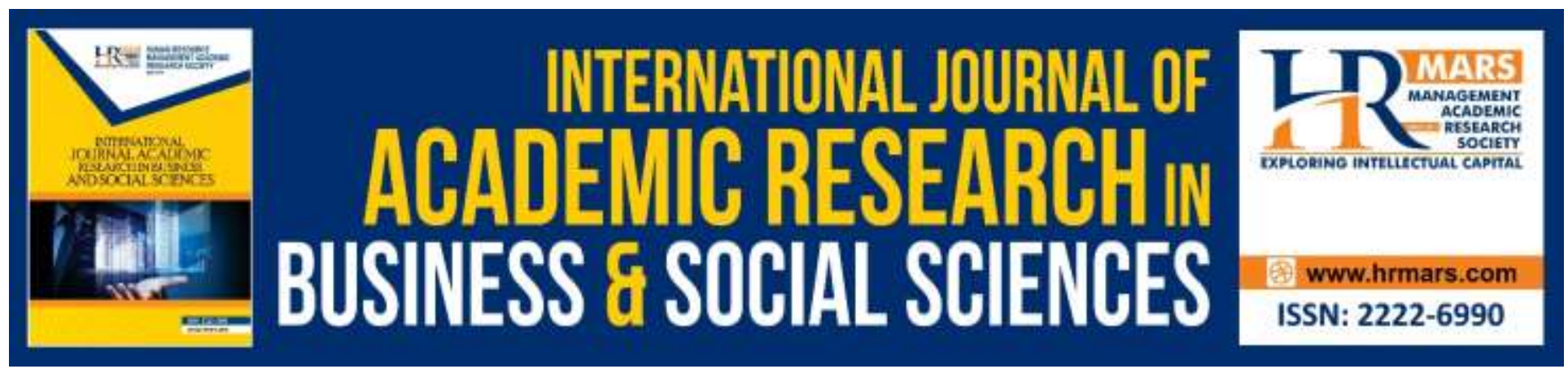

\title{
An Exploratory Study of Integrated Management System on Food Safety and Organic Certifications
}

\author{
1Sarina Abdul Halim Lim, ${ }^{2}$ Anjar Priyono \& ${ }^{1}$ Chew Hueih Ming \\ ${ }^{1}$ Department of Food Technology, Faculty of Food Science and Technology, Universiti Putra, \\ Malaysia, 43400 UPM, Serdang, Selangor, Malaysia, ${ }^{2}$ Department of Management, Universitas \\ Islam Indonesia, Yohyakarta, Indonesia \\ Email: sarinalim@upm.edu.my, anjar.priyono@uii.ac.id, hueihmingchew@gmail.com.
}

\begin{abstract}
This study aims to explore the mechanism of integration of certification process of Organic and Food Safety certifications in the food industry, to determine benefits and challenges associated with the process. The functioning of independent management systems is burdened by duplication of process, steps and documents which, negatively increase the pressure and workload of staff in the organisation. This research was based on semi-structured interviews with six food organic case companies. The result shows the integration can be done at three levels; however the case depicted the implementation of partial integration for the certifications. The alignment process involved the certification policy and objectives, standard operating procedure, pre-requisite program in IMS. Case studies show that benefits and barriers of the implementation of the IMS could be categorised into internal, external and short term, long-term benefits. While the challenges are, training and expert are needed for the integrated system, and there is no guidance on the implementation of the integrated system. Considering the importance of organic certification and food safety certification system, the guideline of IMS implementation is critical for the food businesses to plan their product safety and organic integrity with more effective and efficient approach.
\end{abstract}

Keywords: Integrated Management System, Quality Management System, Food Safety, Organic, Certifications

\section{Introduction}

Organic food has showing increasing trend from the high demand due to consumers' perception that organic foods are healthier and safer than conventional food. Consumers are aware on the food safety and quality and the way the food produced which resulted in an increasing demand for organic products. In organic market, the function of food labelling of food is to protect consumers from fraudulent claims of organic practices being used during production (Geno, 
2001). Trustworthy certification ensures consumers are purchasing good quality products besides the organic labelling.

The certification and labelling provide confidence and quality assurance to consumers, to ensure the marketed organic product was produced according to organic production standard, which may different based on their certifying bodies. Trustworthy certification ensures consumers are purchasing good quality products besides the organic labelling. Organic standards able to avoid veterinary chemicals, pesticide residue, and genetically modified organisms but do not cover much on food safety issues relating to hygiene and water contaminants (Geno, 2001). Chemical, physical and biological hazards that related to food safety need to be determined as there is no inherent protection in the organic standards from viruses and microbial infections. Hence, the food safety program is important to be implemented into organic industry to avoid cross-contamination during the supply chain.

Previous studies such as Abad et al. (2014) and Zeng et al. (2007) reported that the application of various separate management system is usually associated with high operating expenses, efficiency losses, increased of the management overhead, the formation of subcultures in the company and thus a slower exchange of information due to the duplication of tasks and sub-optimal use of resources. It will also burden the employees' job scope due to the confusion between the demands of the individual standards (Villar, 2012). The trend shows the matured organizations choose integrated management system (IMS) to optimise the certification management process (Samy et al., 2015). IMS integrates several management systems into single framework with unified objectives to achieve its mission and vision (Mourougan, 2015). The purpose of this study is to explore the state-of-art of the integrated management system in the food industry in relates to organic and food safety aspect, namely to identify difficulties associated with the certification process, to highlight the main advantages that arise from certification and, to distinguish the level of integration that has been achieved.

\section{Methodology}

A qualitative approach through multiple case studies was used in this study as it is focused on "how" the integration should be done, enable this study to describe individual or group behavior such as benefits and barriers and the sequence of events to integrate the certifications (Yin, 2014). Six case companies from the organic industry involved in the study and their quality assurance team (1-2 executives) were interviewed for average 90 minutes. Sample size of six to eight subjects for a homogenous sample is sufficient in multiple case studies (Crabtree and Miller, 1992). A semi-structured interview is one of the six sources of evidence in case study approach, and it was used in the study as this method allow the researcher to obtain the insight of the importance, advantage and drawback of the certification in their organization, the process of integration of the IMS. In this study, the selections of interviewees were purposive to provide a useful starting point by selecting participants who are thought to be information rich in the area of the quality management system (Keeffe et al., 2016). A cross-case synthesis technique was applied to assess similarities and differences areas of interest that related to the implementation of the IMS such as advantage and challenges of the implementation. Ndonzuau et al. (2002) and Crabtree and Miller (1992) suggest cross-case synthesis able to increase the validity and reliability of the case-study methodology. 


\section{Results and Discussion}

Out of the six companies studied, five were small and medium companies $(A, B, C, D, F, H)$, and company $E$ is classified under big company. Each of the companies consist of multiple management systems including organic management system as based on the nature of the business, it is a requirement for companies to comply to the organic standards as presented in

Table 1.0.

Table 1.0 description of case companies and certifications involved

\begin{tabular}{|c|c|c|c|}
\hline Company & $\begin{array}{l}\text { Number of } \\
\text { employees }\end{array}$ & Nature of business & Certifications \\
\hline$A$ & 58 & $\begin{array}{lr}\text { Organic } & \text { food } \\
\text { repacker } & \text { and } \\
\text { distributor } & \end{array}$ & ISO 22000,NASAA \\
\hline B & 30 & Organic retailer & $\begin{array}{l}\text { NASAA, Organic Crop Improvement } \\
\text { Association }(\mathrm{OCIA})\end{array}$ \\
\hline C & 50 & Noodle Manufacturer & $\begin{array}{l}\text { GMP, HACCP, ISO 22000, BRC Global } \\
\text { Standard, NASAA }\end{array}$ \\
\hline D & 65 & $\begin{array}{lr}\text { Organic } & \text { food } \\
\text { importer } & \text { and } \\
\text { distributor } & \end{array}$ & GMP,HACCP ,BIO-GRO NZ, MyOrganic \\
\hline $\mathrm{E}$ & 250 & Organic distributor & NASAA, MyOrganic \\
\hline $\mathrm{F}$ & 52 & Organic wholesaler & GMP ,NASAA \\
\hline
\end{tabular}

All the case companies are certified by organic certification from NASAA, Australia, except company D was certified under BioGro (New Zealand). NASAA plays a role in the development of the organic industry in Australia by providing certification and audit services to the organic industry, in Australian and internationally (Wynen, 2007). BioGro is New Zealand's largest and best-known organic certifier since 1983 with the nation largest database of organic farmers, producers, and manufactures from New Zealand and across the Pacific. Beside organic certified, company A, D and F were HALAL certified while company $C$ was British Retail Consortium (BRC) certified. Company A, C, D, and F were food safety certified with either Good Manufacturing Practice (GMP), Hazard Analysis and Critical Control Point (HACCP) or International Organization for Standardization (ISO) for Food Safety. GMP, act as pre-requisite program in HACCP, is the minimum sanitary and processing requirements necessary to ensure the production of wholesome food, while HACCP addressed safety in food processing sector in a more comprehensive manner (Mendis and Rajapakse, 2009).

\section{Benefits and Barriers of the Implementation}

Embracing the reality of the growing number of certification, it is essential to explore and analyse the benefits that companies are expected to gain through certification of their management system and the advantage of integrating the certifications. Certifications undoubtedly is a strategic approach for developing organisations as enthusiasm to continuously upgrade and gain 
market stakes. As illustrated in Table 1.0, the reduction of cost in terms of human resources in an organisation is one of the significant advantages of IMS implementation. The advantages and barriers were viewed based on the internal/external and long/short term dimension to provide a more evident awareness of the role of each of the stakeholders and interested parties.

According to company A and B IMS allow the team to operate only on one document for several certifications with similar requirements instead of repeating similar processes, which reduction of time and workforce is evident. This is accordance with a study by Jørgensen (2001) and Lorentzen (1997) that in Danish SME's point of view, IMS reduce the workload of managers since they often have combined duties by dealing with different areas of responsibility at the same time. Moreover, respondents from company $\mathrm{C}$ mentioned that saving of training cost from the IMS implementation was as the management need to allocate budget for the training for each independent management system. Company D identified audit fees for multiple systems could be reduced with the IMS implementation, which is in accordance with a study by Bobrek and Sokovic (2006), provided the level of integration is aligning the processes of audit in IMS manual. Company F confirmed that there was an improvement in operational performance with the IMS implementation through work simplification and duplication of work reduction. Salomone (2008) mentioned Italian companies reduce work reduction by less documentation work subsequently optimisation of human resources. Other benefits include reduction of costs as a result of reducing disparities and ensuring compliance with the legislative and other requirements related to safety and quality (Zeng et al., 2011; Henson and Humphrey,2009; Manning and Baines, 2004; Henson and Hooker, 2001) and achieve optimization by applying a common management approach to several standards (Karapetrovic et al., 2010). Also, manufacturers' reputation can be improved, and opening of the new opportunities for entering new markets are the benefits of IMS implementation (Zeng et al., 2011; Henson et al., 2008; Fulponi, 2006; Mainville et al., 2005; Manning and Baines, 2004). 
Table 1: Advantages and barriers obtained with IMS implementation

\begin{tabular}{|c|c|c|c|}
\hline Internal & External & Internal & External \\
\hline $\begin{array}{l}\text { - Save internal } \\
\text { audit cost } \\
\text { - Document } \\
\text { simplification } \\
\text { - Reduce } \\
\text { training cost } \\
\text { - Reduce } \\
\text { workforce } \\
\text { - Time resources } \\
\text { saved }\end{array}$ & $\begin{array}{l}\text { - Evidence of legal } \\
\text { compliance } \\
\text { - A more agile } \\
\text { system with less } \\
\text { redundancy } \\
\text { - Reduction in } \\
\text { duplication of } \\
\text { policies, } \\
\text { procedures and } \\
\text { method }\end{array}$ & $\begin{array}{l}\text { - Time-consuming } \\
\text { to initiate the } \\
\text { integration } \\
\text { - Lack of training } \\
\text { - Lack of expert in } \\
\text { IMS } \\
\text { - Lack of resources } \\
\text { for integration } \\
\text { - Variances of the } \\
\text { common element } \\
\text { of the } \\
\text { certifications }\end{array}$ & $\begin{array}{l}\text { - Duplication of } \\
\text { effort between } \\
\text { certifiers/verifiers } \\
\text { and internal } \\
\quad \text { auditors } \\
\text { - Different } \\
\text { stakeholders } \\
\text { demand }\end{array}$ \\
\hline $\begin{array}{l}\text { - Integrated } \\
\text { external audit } \\
\text { - Improve } \\
\text { operational } \\
\text { performance } \\
\text { of } \\
\text { new standard } \\
\text { - Improvement } \\
\text { in } \\
\text { organisations } \\
\text { global strategy } \\
\text { - Cost reduction } \\
\text { in } \\
\text { management }\end{array}$ & $\begin{array}{l}\text { - Improvement of } \\
\text { relations with } \\
\text { stakeholders } \\
\text { - Company image } \\
\text { improvements' } \\
\text { Gain new } \\
\text { customers/satisfy } \\
\text { existing ones } \\
\text { - Company image } \\
\text { improvements }\end{array}$ & $\begin{array}{l}\text { - Lack of guideline } \\
\text { for the } \\
\text { implementation } \\
\text { - Lack of } \\
\text { employees } \\
\text { motivation } \\
\text { - Cultural } \\
\text { differences } \\
\text { between } \\
\text { disciplines of } \\
\text { certifications }\end{array}$ & $\begin{array}{l}\text { - Uncertainty } \\
\text { about the value } \\
\text { of IMS in the } \\
\text { market place } \\
\text { - Lack of } \\
\text { government } \\
\text { support } \\
\text { - Lack of sector } \\
\text { specific } \\
\text { implementation } \\
\text { tools and } \\
\text { examples }\end{array}$ \\
\hline
\end{tabular}

However, the difficulties associated with IMS implementation refers to across some challenges in the process of integration., which similarly reported by Karapetrovic and Willborn (1998) and Karapetrovic (2003). Results from the interview showed that the IMS would be timeconsuming and ineffective if there is lack of training, absent of expert in IMS and no guideline for the IMS system. Respondents from company A, B and E highlighted that during the initial stage, the team need time to familiarise with the new system and it takes time to handle the system at the same time ensuring any core elements in the certifications are not compromised. As mentioned by one of the respondents with four certifications in the organisation, their team facing difficulties to decide which to integrate as there was no guidance provided for the integration, especially in organic and food safety certifications. 
It was also identified in the study; SMEs companies are struggling to implement IMS although characteristics of IMS is customized with the need of SMEs. Hines (2002) conducted a study in South Wales, UK found that small SMEs were less interested in IMS than the large organisations due to the intrusion of a new system might erode the position of the present system manager. The industries also facing difficulties in analysing and processing of a large amount of information and clauses that need to be integrated during the implementation (Karaman et al., 2012; Trienekens and Zuurbier, 2008; Henson et al., 2005; Martinez and Poole, 2004). Other issues reported by the case companies are such as the changes one certifications required changes both certifications manual within the IMS and even professional and cultural conflicts also occur due to unsuitable integration process (Santos et al., 2011).

\section{Towards Structuring the IMS}

The experience of company A implementing the integration of safety and organic management system is applied in this section and forward as company A are certified both ISO22000 (food safety) and NASAA (organic). In this study, a partially integrated system was implemented with IMS manual, which contains unified procedures (Figure 1.0). A partially integrated system keeps its manuals separated using integrated procedures of several similar processes (Karapetrovic. 2003, Santos et al., 2011).

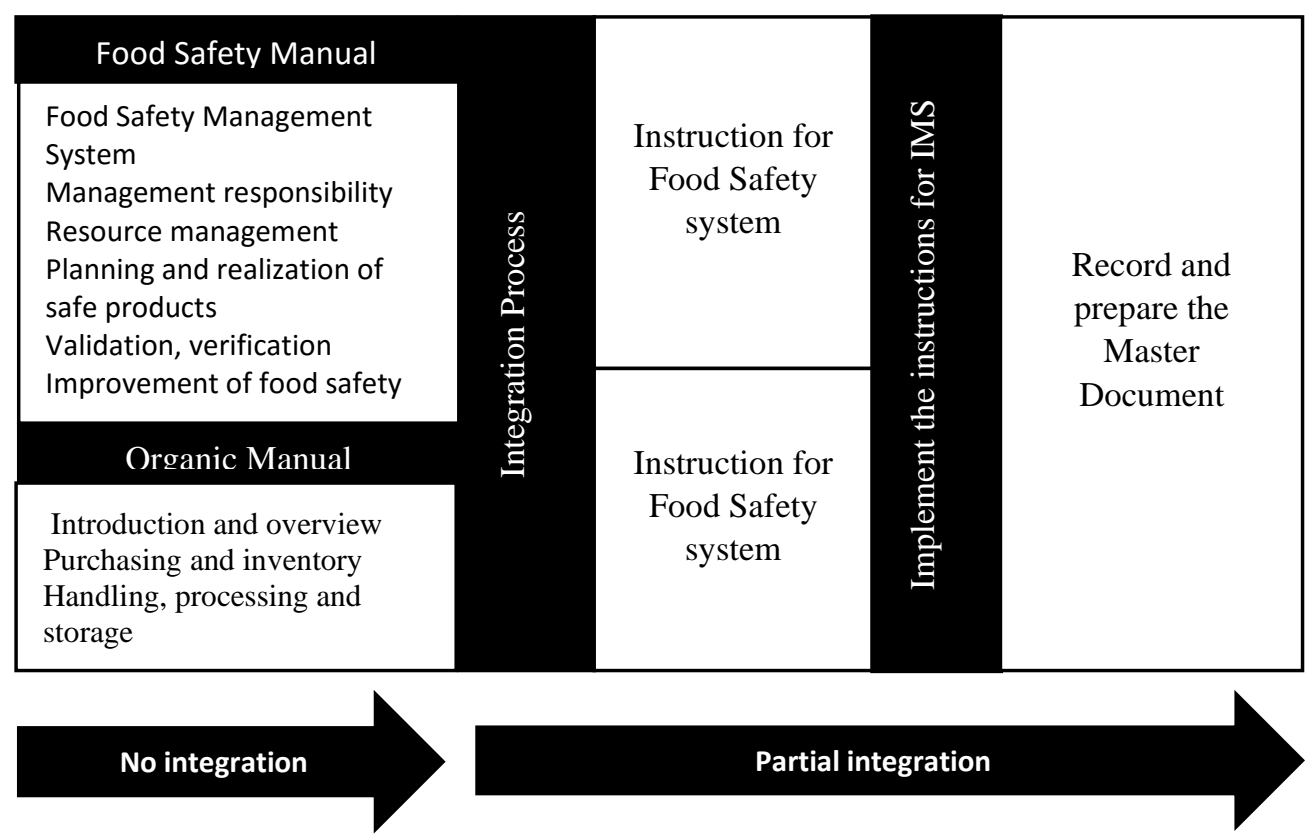

Figure 1.0 Steps in the integrated management manual

Compatibility, alignment, cross-references and internal coordination of the elements in the management system were the initial steps because the certifications share many common features. The integration of the certifications is through making cross-reference both manuals, as illustrated in Table 2.0, reduce the add-on problem of different parallel management system in one organisation. 
Table 2.0: Example of alignment between elements HACCP and NASAA

\begin{tabular}{l|l}
\hline Food safety certifications & Organic certifications \\
\hline 4.1.1 Scope of certification & \\
\hline 4.1 General requirements & 9.8 Dorm Map \\
4.2.3 Control of Records & \\
\hline 6.2.2 Competence, & 8.1 Social Justice \\
awareness and training & 9.1 Processing \\
\hline 7.2 Prerequisite & 9.2 Transport \\
programmes (PRPs) & 9.3 Storage and Warehousing \\
& 9.6 Handling and Packing \\
& 9.7 Pest Control \\
& 9.9 Best Environmental Practice \\
\hline 7.10.4 Withdrawals & 9.10 Product Recall
\end{tabular}

The aligned clauses were the scope of certification, control of records, competence, awareness and training, pre-requisite program and withdrawals. These five clauses had common requirements; thus, the procedure can be integrated into a single step process for each of them.

\section{Continuous Improvement Cycle}

The strategies for IMS implementation are primarily limited, and the current models reviewed were based on incomplete methodologies for the full integration (Asif et al. 2009, Nunhes et al., 2019). Based on the interview, it was stated the effectiveness of integrated management system is depended on the level of the integration and approach for implementing the IMS either by structure of documents or process focus. Most of the companies mentioned that the IMS should maintain the generic processes of both certifications. Jorgensen et al. (2006) highlight that understanding generic processes and task is a prerequisite for the integration to commence. Instead of structure of the element, the process focus approach is fundamental to motivate the organisations to emphasis on continuous improvements in ensuring the organic integrity and safeness of the food are continuously secured. Continuous improvement is one of the six pillars in IMS where such approach should present a cycle consist of opportunities for improvement at all the processes of the company across all level which actions, resources and goals were described (De Oliveira, 2013, Domingues et al., 2016, Shevchenko, 2018).

In the newest version for most of the management standards, the changes from the previous version are the manual based on process focus, prevention through risk assessment and continuous improvement which the principles of Plan-Do-Check-Act as a strategy for process 
approach. Planning phase requires the development of definition of context of the organisation, leadership and planning and support from the top management. Doing phase emphasises the operational aspect of the certifications such as communicate the IMS to the interested parties, implement the IMS, structure and implement contingency plan, structure and implement the needed Operational Instruction and outsourced process. Check is the performance of food safety, and organic aspect is assessed through periodic assessment and analysis and documentation of the analysis which can be evidence of its compliance of the IMS. Finally, Act phase, continuous improvement is embedded such as corrective action, non-conformities reduction plan, audits and periodic management review.

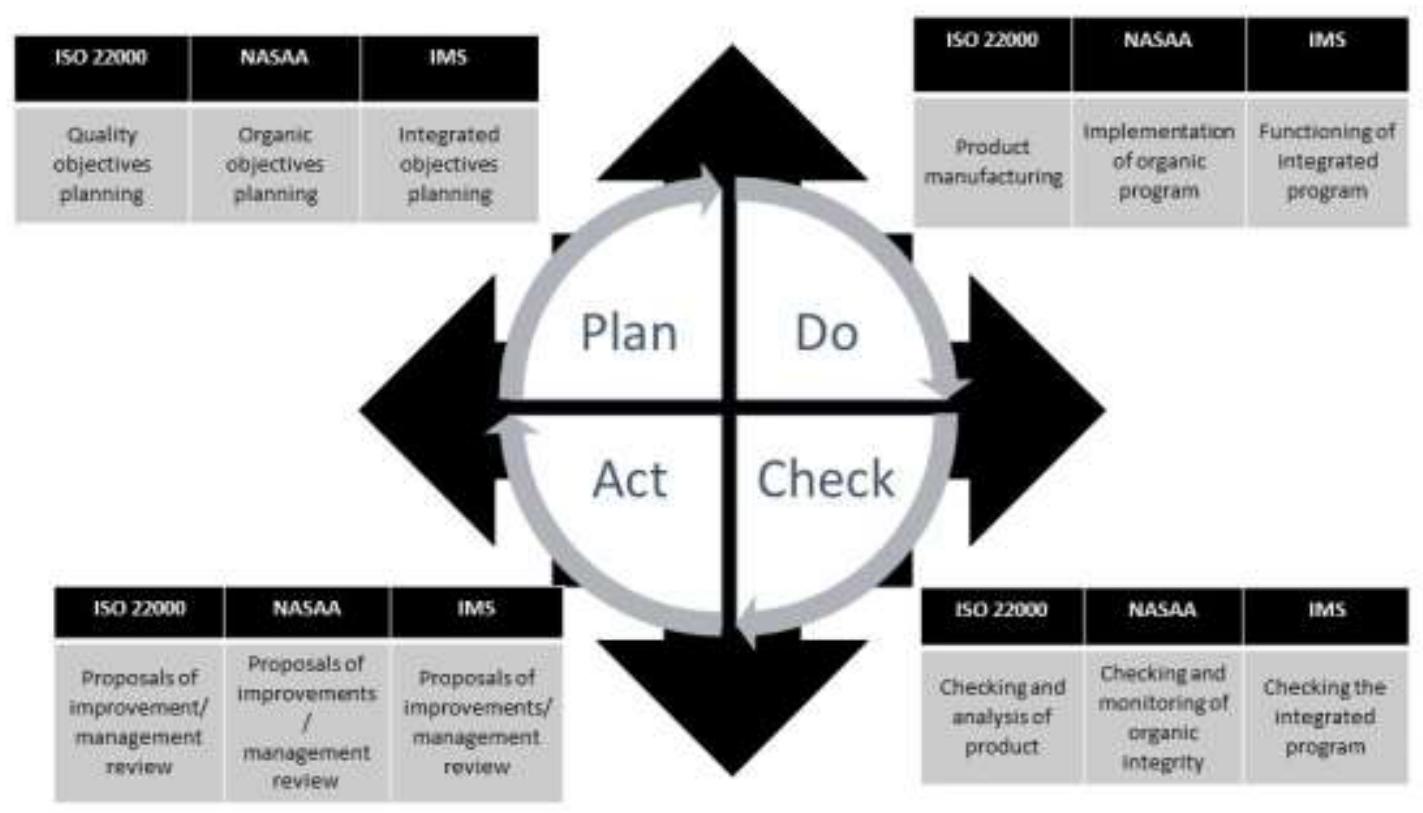

Figure 2.0 Deming's PDCA cycle for IMS food safety and organic

Through the approach of alignment in Figure 2.0, it enables the organisation sync their organisational process and develop a practical referential method to support effective integration of organic and food safety elements at the level of partial integration (Robelo et al., 2016).

\section{Conclusion}

Rapid global development in the food industry leads to a critical demand to address the expectation of stakeholders, in which most of the food businesses are facing the need to comply with several certifications. The objective of the paper is to explore the benefits and barriers for integrating the food safety and organic certifications and to identify the level and develop IMS for both of the certifications. The conclusion is the integration of a number of management systems in-compared to individual implementation of management system constitutes added value both in the short and long-term impact. Integration of both organic and food safety certification into a single implementation framework is a strategic approach for a significant cost 
reduction and time-saving in the certification process in maintaining the organic and food safety integrity of the products. However, the common barriers identified such as lack of knowledge, skills and awareness of the IMS methodologies should be tackle through strategic training programme by the management. The result of the study suggested scope of certification, policy and objectives, document control, employee training, internal audits and management responsibilities are appropriate to be integrated at partial integration level. These results could be useful for the food businesses wanting to integrate their food safety and organic certification, strategically plan the implementation of IMS in the company.

\section{Acknowledgements}

The authors would like to acknowledge Ministry of Education, Malaysia under Fundamental Research Grant Scheme (FRGS/1/2018/TK03/UPM/02/7) for the support and the resources provided for the present study. Also, acknowledge the constructive and helpful comments by reviewers which helped to improve the presentation of the paper considerably.

\section{Corresponding Author Email:}

sarinalim@upm.edu.my

\section{References}

Asif, M., Bruijn, E. J., Fisscher, O. A. M., Searcy, C., Steenhuis, H.-J. (2009). Process embedded design of integrated management systems. International Journal of Quality and Reliability Management 26, 261-282

Bernardo, M., Gotzamani, K., Vouzas, F., \& Casadesus, M. (2018). A qualitative study on integrated management systems in a non-leading country in certifications. Total Quality Management \& Business Excellence, 29(3-4), 453-480.

Bobrek, M., and Sokovic, M. (2006). Integration concept and synergetic effect in modern management. Journal of Materials Processing Technology 175:33-39.

De Oliveira, O. J. (2013). Guidelines for the integration of certifiable management systems in industrial companies. Journal of Cleaner Production, 57, 124-133.

Domingues, Pedro, Sampaio, P., and Pedro, M. A. (2016) Integrated management systems assessment: a maturity model proposal. Journal of Cleaner Production, 124, 164-174.

Fulponi, L. (2006). Private Voluntary Standards in the Food System: The Perspective of Major Food Retailers in OECD Countries. Food Policy 31 (1): 1-13.

Rural Industries Research and Development Corporation. (2001). Integrating Organic Certification with Food Safety Certification Systems- A Briefing Paper. AgriFutures Australia. https://www.agrifutures.com.au/wp-content/uploads/publications/01-171.pdf

Jørgensen, T. H., Remmen, A., \& Mellado, M. D. (2006). Integrated management systems-three different levels of integration. Journal of cleaner production, 14(8), 713-722.

Jørgensen, T. H. (2001). Miljøledelse: systemer, standarder og praksis. Institut for Samfundsudvikling og Planlægning, Aalborg Universitet. ISP-Skriftserie, No. 277.

Karapetrovic, S., and Jonker, J. (2003). Integration of standardized management systems: Searching for a recipe and ingredients. Total Quality Management \& Business Excellence 14(4):451-459. 
Karapetrovic, S., and Willborn, W. (1998). Integrated audit of management systems. International Journal of Quality \& Reliability Management 15(7): 694-711.

Karapetrovic, S. (2002). Strategies for the integration of management system and standards. The TQM Magazine 14(1): 61-67.

Karaman, A., Cobanoglu, F., and Tunalioglu, R. (2012). Barriers and benefits of the implementation of food safety management systems among the Turkish dairy industry: a case study. Food Control 25 (2): 732-739.

Keeffe, J. O., Buytaert, W., Mijic, A., Brozovic, N., and Sinha, R. (2016). The use of semi-structured interviews for the characterization of farmer irrigation practices. Hydrology and Earth System Sciences 20:1911-1924.

Mendis, E., and Rajapakse, N. (2009). GMP and HACCP: A Handbook for Small and Medium Scale Food Processing Enterprises. Colombo: The Ceylon Chamber of Commerce.

Myers, M. D. (2009). Qualitative research in business and management. London: Sage.

Nunhes, T. V., Vilamitjana, M. B., \& Oliveira, O. J. (2019). Guiding principles of integrated management systems: Towards unifying a starting point for researchers and practitioners. Journal of cleaner production 210, 977-993.

Ndonzuau, F. N., and Pirnay, F. (2002). A stage model of academic spin-off creation. Technovation, Vol. 22 No. 5, pp. 281-9

Nunhes, T. V., \& Oliveira, O. J. (2018). Analysis of Integrated Management Systems research: identifying core themes and trends for future studies. Total Quality Management \& Business Excellence, 1-23.

Rebelo, M. F., Santos, G., \& Silva, R. (2016). Integration of management systems: towards a sustained success and development of organizations. Journal of Cleaner Production, 127, 96-111.

Salomone, R. (2008). Integrated management systems: experiences in Italian organizations. Journal of Cleaner Production 16, 1786-1806.

Samy, G. M., Samy, C. P., and Ammasaiappan, M. (2015). Integrated management systems for better environmental performance and sustainable development-a review. Environmental Engineering and Management Journal 14(5): 985-1000.

Santos, G., Mendes, F., \& Barbosa, J. (2011). Certification and integration of management systems: the experience of Portuguese small and medium enterprises. Journal of cleaner production, 19(17-18), 1965-1974.

Shevchenko, A., Pagell, M., Johnston, D., Veltri, A., \& Robson, L. (2018). Joint management systems for operations and safety: A routine-based perspective. Journal of cleaner production, 194, 635-644.

Zeng, S., Xie, X., Tam, C., and Shen, L. (2011). An empirical examination of benefits from implementing integrated management systems (IMS). Total Quality Management 22 (2): 173-86. 